\title{
PENTINGNYA PENGGUNAAN SUPERVISI SECARA EFEKTIF DALAM PENDIDIKAN
}

\author{
LATIFATUL HUSNI \\ Latifahusni1998@gmail.com
}

\begin{abstract}
ABSTRAK
Artikel ini bertujuan untuk mengetahui bagaimana pentingnya penggunaan supervisi secara efektif dalam pendidikan. Dilihat dari mutu pendidikan di indonesia yang saat sekarang ini masih jauh tertinggal di dunia internasional. Dilihat dari sumber daya manusia yang belum memadai, serta teknologi dan ilmu pengetahuan yang tidak merata di indonesia. Kepala sekolah dan guru yang belum melaksanakan tugasnya untuk pelaksanaan pembelajaran dengan baik. Kepala sekolah yang belum baik dalam mengawasi guru mengajar serta guru yang hanya bertugas mengajar saja, padahal seorang guru itu tugasnya juga untuk membentuk karakter siswa. Dalam artikel ini akan dibahas apa yang dimaksud dengan supervisi, bagaimana pelaksanaan supervisi, dan apa upaya untuk meningkatkan supervisi. Supervisi merupakan bantuan kepada guru dalam perbaikan situasi belajar-mengajar, supervisi pendidikan meliputi supervisi terhadap pengajaran maupun komponen pendukungnya. Supervisi pengajaran merupakan kegiatan yang berhubungan langsung dengan pengajaran tetapi tidak langsung dengan siswa. Kegiatan supervisi dilaksanakan melalui berbagai proses pemecahan masalah pengajaran.
\end{abstract}

Kata kunci : supervisi; pendidikan

\section{LATAR BELAKANG}

Sebagai lembaga pendidikan formal, sekolah diharapkan mampu untuk meningkatkan mutu pendidikan di indonesia. Pendidikan di Indonesia pada saat sekarang ini belum mencapai pada keadaan yang seharusnya. Jika dibandingkan dengan negara-negara maju yang pendidikan nya jauh lebih baik daripada indonesia. Mutu dan kualitas yang rendah serta tujuan pembelajaran yang belum tercapai. Dikarenakan perkembangan teknologi dan ilmu pengetahuan yang belum merata ke daerah-daerah. Oleh karena itu perlu adanya pemerataan di wilayah-wilayah terpencil yang belum tersentuh oleh teknologi.

Untuk tercapainya pendidikan yang berkualitas diperlukan guru yang profesional, berkualitas dan memenuhi kompetensi-kompetensi yang dipersyaratkan. Kemampuan profesional yang harus dimiliki seorang guru menurut Glasser (Sudjana, 2002: 13) "adalah (1) menguasai bahan pelajaran, (2) kemampuan mendiagnosa tingkah laku siswa, (3) kemampuan melaksanakan proses pengajaran, (4) kemampuan mengukur proses belajar siswa".

Supervisi akademik tidak terlepas dari penilaian kinerja guru dalam mengelola pembelajaran. Perlu juga adanya peningkatan kualitas sumber daya manusia untuk 
meningkatkan kualitas pendidikan di indonesia. Pentingnya pendidikan ini juga mengingat bahwa harus berkembang dan berubah sesuai dengan perkembangan zaman. Maka dari itu pendidik juga harus menyesuaikan dengan perkembangan zaman.

Pada kondisi sekarang pelaksanaan supervisi oleh kepala sekolah dan guru masih kurang terlaksana. hal ini dapat dilihat dari kinerja guru. Banyak guru-guru yang hanya melaksanakan tugas hanya mengajar saja, padahal tugas guru itu adalah juga untuk membentuk karakter siswa. Begitu juga dengan kepala sekolah, yang tidak bisa meningkatkan kualitas kerja serta prestasi sekolah.

Kepala sekolah dalam pelaksanaan supervisi bukan hanya menilai kinerja seorang guru saja tetapi semua kegiatan yang berhubungan dengan proses pembelajaran. Hal ini didukung pernyataan oleh Glickman (1981: 34), yang mengatakan supervisi akademik adalah serangkaian kegiatan membantu guru mengembangkan kemampuannya mengelola proses belajar mengajar demi pencapaian tujuan pengajaran.

Sabandi mengemukakan (Sabandi, 2013)supervisi pendidikan ini berkembang seiring dengan perkembangan ilmu pengetahuan teknologi, serta sosial ekonomi dan budaya masyarakat. Supervisi bergerak dariberbentuk inspeksi dimana otoritas lebih didominasi oleh supervisor, berkembang dalam bentuk kolaborasi antara supervisor dan guru bersama berinisiatif dan bertanggungjawab dalammeningkatkan kualitas pembelajaran, serta menumbuhkan budaya belajar pada guru untuk selalu meningkatkan kompetensinya.

Menurut Arifin (2000:56) di dalam artikel maralih (Maralih, 2014) guru itu dikatakan profesional atau tidak dapatdilihat apabila guru mempunyai: 1) dasar ilmu pengetahuan yang kuat (latar belakang pendidikan) sebagai pengejawatan terhadap teknologi dan ilmu pengetahuan, 2) penguasaan kiat-kiat profesi berdasarkan riset dan praksis pendidikan bukan merupakan konsep-konsep belaka, 3) kematangan profesional berkesinambungan, 4) memiliki kepribadian matang dan berkembang dan 5) keterampilan untuk membangkitkan peserta didik kepada sains dan teknologi.

Rumusan masalah dari artikel ini adalah (1) bagaimana pengertian supervisi, (2) bagaimana pelaksanaan supervisi, (3) bagaimana upaya meningkatkan supervisi.

\section{PEMBAHASAN}

1. Pengertian supervisi

Dalam praktiknya, supervisi akademik diberikan oleh kepala sekolah kepada guru dalam rangka memperbaiki kinerja, hal ini berdasarkan pernyataan Pupuh Fathurrohman (2011: 8) bahwa pada dasarnya supervisi pendidikan dapat diartikan sebagai bantuan yang diberikan oleh kepala sekolah untuk melaksanakan penilaian dan supervisi dari segi teknis pendidikan dan administrasi dalam bentuk arahan bimbingan dan contoh pelaksanaan mengajar. Pernyataan diatas sesuai fakta di lapangan karena memang sudah menjadi tugasnya kepala sekolah untuk menjadi supervisor terhadap guru maupun karyawannya di satuan-satuan pendidikan. seperti yang telah penulis tanyakan kepada pengawas pendidikan di Kabupaten Karanganyar, bahwa supervisi oleh kepala sekolah sudah berjalan namun belum maksimal. (Fatkhurokhim, 2016)

\section{Pelaksanaan Supervisi}


Pelaksanaan supervisi dilaksanakan oleh pelaku supervisi dan subjek yang akan disupervisi, pelaku supervise adalah unsur yang paling dekat atau langsung terlibat dengan prestasi belajar siswa, yaitu: Pengawas, Kepala Sekolah, Wakil Kepala Sekolah bidang kurikulum atau akademik, wali kelas, petugas bimbingan dan konseling, serta petugas perpustakaan, sementara subjek supervise adalah guru dan pegawai.

Sasaran utama supervisi pendidikan adalah untuk melakukan-pembinaan terhadap guru-guru agar dapat melakukan semua tugas dengan lebih baik. sebagai supervisor harus mampu mengadakan pengendalian dan supervisi terhadap tenaga kependidikan khususnya guru dengan tujuan meningkatkan kemampuan profesi guru dan kualitas proses pembelajaran

Dalam pelaksanaan supervise ada beberapa teknik supervisi yang dapat dipilih dan digunakan supervisor meliputi: 1) Kunjungan kelas, 2) Kunjungan sekolah, 3) Ujian dadakan, 4) Konfrensi kasus, 5) Observasi Dokumen, 6) Wawancara, 7) Angket, 8) Laporan. Supervisi yang dilakukan kepala sekolah terhadap guru meliputi (1) masalah wawasan dan kemampuan profesional guru, (2)masalah kehadiran dan aktiviti guru, (3) masalah persiapan mengajar guru, mulai dari analisa bahan mata pelajaran pelajaran, program tahunan, program semester, program satuan pelajaran, pembuatan mata pelajaran sampai dengan persiapan mengajar harian atau rencana pelaksanaan pembalajaran, (4) Masalah pencapaian tujuan kurikuler dan pelaksanaan ekstrakurikuler, (5) penguasaan bahan ajar, (6) penggunaan metode pembelajaran, (7) penggunaan alata peraga/praktek, (8) pengaruh timbal balik pembelajaran, (10) penilaian hasi belajar pelajar, (8) tindak lanjut hasil penilaian pembelajaran mata pelajaran. (9) masalah kerjasama guru dengan pelajar, dengan sesama guru, tata usaha dan dengan kepala sekolah.

\section{Upaya Dalam Meningkatkan Supervisi}

Kepala sekolah diharapkan dapat menyusun suatu program supervisi yang mampu memberikan bantuan kepada guru-guru agar mereka memperbaiki dirinya sendiri secara maksimal.Supervisi pada hakekatnya melakukan pengawasan terhadap proses pendidikan di sekolah, kegiatan supervisi masuk ke dalam jalinan interaksi kepala sekolah dengan guru didalam kegiatan belajar mengajar. Peningkatan kualitas diri guru dapat dilakukan melalui layanansupervisi pengajaran kepala sekolah. Layanan supervisi itu bertujuan untuk meningkatkan profesionalisme, dalam proses pembelajaran. Peningkatan kinerjadan profesionalisme guru sangat diperlukan, karena peningkatan kinerja dan profesionalisme guru; "tidak hanya dilakukan terhadap guru di Negaraberkembang tetapi juga banyak Negara maju pun, sekarang ada kecenderunganuntuk meningkatkan kompetensi guru dan mengembangkan profesi guru secara terus menerus" (Kuntoro; 1890:59), Supeno (1995:49).

Program-program supervisi hendaknya memberikan rangsangan terhadap terjadinya perubahan dalam kegiatan pengajaran. Perubahan - perubahan itu dapat dilakukan antara lain melalui berbagai usaha inovasi dalam pengembangan kurikulum serta kegiatan pendidikan dan pelatihan dalam jabatan untuk guru. Kepala sekolah harus menguasai langkah-langkah dalam pelaksanaan supervisi khususnya supervisi peggajaran beserta tujuannya. Supervisi merupakan suatu usaha untuk memberikan pelayanan perbaikan situasi mengajar belajar yang direncanakan secara hati-hati. Supervisi oleh kepala sekolah haruslah diarahkan untuk memberikan bantuan dan bimbingan serta pembinaan kepada guru-guru agar mereka mampu bekerja lebih baik dalam membimbing pelajarnya. 
Di dalam pelaksanaan supervisi, sikap kooperatif guru yang ditnjukan dalam fase perencanaan tetap masih diperlukan, malahan perlu ditingkatkan. Kesediaan guru untuk diobservasi dan dianalisis perilaku mengajarnya, serta kesediaan untuk berdialog dengan supervisor harus terus dikembangkan, sehingga guru dapat memperoleh manfaat sebesarbesarnya dari proses supervisi.

Dalam peningkatan kualitas supervisi, seorang kepala sekolah perlu memenuhi kompetensi umum maupun kompetensi khusus. Kompetensi umum meliputi (1) Bertindak demokratis, bersifat terbuka/transparan, menghormatipendapat orang lain, mampu berkomunikasi dengan baik dan menjalin kerjasama dengan berbagai pihak terkait, (2) memiliki kepribadian yang menarik dan simpatik serta mudah bergaul, (3) Bersifat ilmiah dalam segala hal serta memiliki prinsip mau terus belajar, (4) Memiliki dedikasi tinggi serta layak pada tugas dan jabatannya, (5) Menghindarkan diri dari sifat-sifat tercela, (6) Memandang guru dan seluruh staf sekolah sebagai mitra kerja, bukan sebagai bawahan. Adapaun kemampuan khusus seorang supervisor adalah: (1) Memiliki pengetahuan tentang manajemen pendidikan secara umum dan manajemen sekolah secara khusus, yang meliputi manajemen personil, manajemen bahan mata pelajaran dan manajemen operasional, (2) Memiliki pengetahuan tentang supervisi pendidikan, yang meliputi tujuan dan sasaran, teknik-teknik, langkah-langkah dan prinsip-prinsip dasar supervisi pendidikan, (3) Menguasai subtansi bahan mata pelajaran pengawasan pendidikan, yang meliputi kurikulum, proses pembelajaran, kesimpulan dan lain-lain, (4) Menguasai subtansi bahan mata pelajaran supervisi teknik manajemen, yang antara lain: adminstrasi sekolah, adminstrasi kepegawaian, adminstrasi kurikulum, pengelolaan perpustakaan, laboratorium dan sebagainya, (5) Memiliki kemampuan berkomunikasi, membina dan memberi contoh-contoh tentang pelaksanaan kegiatan belajar, mengajar yang baik, (6) Memiliki kemampuan mediator antara guru dengan guru, antara seluruh stap sekolah dengan instansi terkait, dan lain-lain, (7) Memiliki kemampuan membimbing guru dalam hal perolehan angka kredit dan membuat karya tulis/ilmiyah, (8) Harus bekerja sesuai dengan rencana dan tujuan yang telah ditetapkan, (9) Harus memiliki kepatuhan terhadap peraturan perundang-undangan yang berlaku dan harus menjunjung tinggi kode etik jabatan .

Maralih juga mengatakan (Maralih, 2014)Kepala sekolah membuat rencana, program dan pelaksanaan supervisi yang telah disepakati bersama dengan guru. Kegiatan supervise diawali dengan perencanaan supervisi yang matang, Agar supervisi dapat dijalankan dengan baik kepala madrasah harus terlebih dahulu membuat rencana dan program supervisi, Kemampuan menyusun program supervisi pendidikan harus diwujudkan dalam penyusunan program supervisi kelas, pengembangan program supervisi untuk kegiatan ekstra kurikuler, program pengambangan supervisi perpustakaan, laboratorium dan ujian. Kemampuan melaksanakn program supervisi pendidikan harus diwujudkan dalam pelaksanaan program supervisi klinis, program supervisi non klinis, dan program supervisi kegiatan ekstrakurikuler. Sedangkan kemampuan memanfaatkan hasil supervisi pendidikan harusmeningkatkan prestasi kerja tenaga kependidikan, dan pemanfaatan hasil supervisi untuk mengembanngkan madrasah (Mulyasa, 2004). 


\section{KESIMPULAN}

Kualitas proses belajar mengajar sangat dipengaruhi oleh kualitas kinerja guru, untuk itu sumber daya guru itu perlu terus menerus bertumbuh dan berkembang agar dapat melakukan fungsinya secara professional, mendorong guru-guru untuk terus menerus belajar menyesuaikan diri dengan perkembangan ilmu pengetahuan dan teknologi.

Supervisi mengembangkan dan meningkatkan kualitas guru sehingga guru tersebut dapat berkembang dalam pekerjaannya. Kegiatan supervisi dilaksanakan melalui berbagai proses pemecahan masalah pengajaran. Tujuannya adalah untuk meningkatkan efektivitas dan efisiensi proses belajar-mengajar. Supervisi merupakan bantuan kepada guru dalam perbaikan situasi belajar-mengajar, supervisi pendidikan meliputi supervisi terhadap pengajaran maupun komponen pendukungnya. Supervisi pengajaran merupakan kegiatan yang berhubungan langsung dengan pengajaran tetapi tidak langsung dengan siswa. Kegiatan supervisi dilaksanakan melalui berbagai proses pemecahan masalah pengajaran. 


\section{REFERENSI}

Fatkhurokhim, H. (2016). supervisi pendidikan, kinerja guru. (3), 114-120.

Maralih. (2014). PERANAN SUPERVISI DALAM PENINGKATAN KUALITAS PENDIDIKAN Oleh Maralih Abstrak. 1(1), 179-192.

Sabandi, A. (2013). Supervisi Pendidikan Untuk Pengembangan Profesionalitas Guru Berkelanjutan. Jurnal Ilmiah Ilmu Pendidikan, XIII(2), 1-9. Retrieved from https://scholar.google.co.id/citations?user=hDQ7k_AAAAAJ\&hl=id\#d=gs_md_cita$\mathrm{d} \& \mathrm{u}=\% 2 \mathrm{Fcitations} \% 3 \mathrm{Fview}$-op $\% 3$ Dview_citation $\% 26 \mathrm{hl} \% 3 \mathrm{Did} \% 26$ user $\% 3 \mathrm{DhDQ} 7 \mathrm{k}$ AA AAAJ\%26citation_for_view $\% 3 \mathrm{DhDQ} 7 \mathrm{k} \_\mathrm{AAAAAJ} \% 3 \mathrm{Au} 5 \mathrm{HHmVD}$ _uO8C $\% 26$ tzom $\% 3 \mathrm{D}$ $-420$ 